\title{
Quality of the hospital infection control programs: an integrative review
}

\author{
Qualidade dos programas de controle de infecção hospitalar: \\ revisão integrativa \\ Calidad de los programas de control de infecciones hospitalarias: \\ revisión integradora
}

\section{André Luiz Silva Alvima \\ Bráulio Roberto Gonçalves Marinho Couto \\ Andrea Gazzinellia}

\section{How to cite this article:}

Alvim ALS, Couto BRGM, Gazzinelli A. Quality of the hospital infection control programs: an integrative review. Rev Gaúcha Enferm. 2020;41:e20190360. doi: https://doi.org/10.1590/19831447.2020.20190360
- Universidade Federal de Minas Gerais - UFMG, Escola de Enfermagem, Programa de Pós-Graduaçăo em Enfermagem, Belo Horizonte, Minas Gerais, Brasil.

${ }^{\mathrm{b}}$ Centro Universitário de Belo Horizonte (UniBH), Departamento de Engenharia e Estatística, Belo Horizonte, Minas Gerais, Brasil.

\section{ABSTRACT}

Objective: To analyze the quality of health in relation to the components of structure, process, and outcome in actions for the prevention and control of infections.

Method: An integrative literature review in the LILACS, Web of Science, Scopus, and SciELO databases. The time delimitation covered articles published between January 2009 and May 2019.

Results: The final sample consisted of 10 articles published, mainly in Scopus (60\%), and in Web of Science (30\%). The structural elements varied among the study countries, suggesting opportunities for improvement of organizational characteristics and human resources. Regarding the process of the implemented routines, inconsistencies were found to comply with the guidelines. The result component was not emphasized among the studies included in the review.

Conclusion: The quality of hospital infection control programs has yet to be improved among the health services, highlighting the need for investment in the structure, process, and outcome components.

Keywords: Hospital infection. Hospital infection control program. Quality of health care.

\section{RESUMO}

Objetivo: Analisar a qualidade em saúde em relação aos componentes de estrutura, processo e resultado nas ações de prevenção e controle de infecções.

Método: Revisão integrativa da literatura nas bases de dados da LILACS, Web of Science, Scopus e SciELO. A delimitação temporal abrangeu artigos publicados entre janeiro de 2009 e maio de 2019.

Resultados: A amostra final foi de 10 artigos publicados, principalmente no Scopus (60\%) e na Web of Science (30\%). Os elementos estruturais variaram entre os países de estudo, sugerindo oportunidades de melhoria das características organizacionais e dos recursos humanos. Em relação ao processo das rotinas implantadas, foram encontradas inconsistências ao cumprimento das diretrizes. 0 componente resultado não obteve ênfase entre os estudos incluídos na revisão.

Conclusão: A qualidade dos programas de controle de infecção hospitalar ainda precisa ser aprimorada entre os serviços de saúde, destacando a necessidade de investimentos nos componentes de estrutura, processo e resultado.

Palavras-chave: Infecção hospitalar. Programa de controle de infecção hospitalar. Qualidade da assistência à saúde.

\section{RESUMEN}

Objetivo: Analizar la calidad de la salud en relación con los componentes de estructura, proceso y resultado en las acciones para la prevención y control de infecciones.

Método: Revisión bibliográfica integradora en bases de datos LILACS, Web of Science, Scopus y SciELO. La delimitación temporal abarcó artículos publicados entre enero de 2009 y mayo de 2019.

Resultados: La muestra final consistió en 10 artículos publicados, principalmente en Scopus (60\%) y Web of Science (30\%). Los elementos estructurales variaron entre los países del estudio, lo que sugiere oportunidades para mejorar las características de la organización y los recursos humanos. Con respecto al proceso de las rutinas implementadas, se advirtieron inconsistencias para cumplir con las pautas. El componente de resultados no se enfatizó entre los estudios incluidos en la revisión.

Conclusión: La calidad de los programas de control de infecciones hospitalarias aún no se ha mejorado entre los servicios de salud, razón por la cual, se destaca la necesidad de invertir en los componentes de estructura, proceso y resultados.

Palabras clave: Infección hospitalaria. Programa de control de infecciones hospitalarias. Calidad de la atención de salud. 


\section{口INTRODUCTION}

Quality in health aims to effectively meet the needs of the patient, providing safe care, and maximum well-being, in its most complete and extended forms ${ }^{(1)}$. In the health services, the search for quality assessment becomes a constant, reflecting a culture of excellence that provides improved care to achieve patient safety ${ }^{(2-3)}$.

It is highlighted that the theme is widely discussed among the health professionals and its definition still varies in the literature. In this study, the construct of quality in health is adopted through the evaluation of the components of structure, process, and outcome. This interdependent triad supports systematic research and concerns the organizational infrastructure, the activities developed in the health services and the quality indicators that reflect the care for the patient ${ }^{(3)}$.

Among the various problems that affect the quality of care and negatively impact patient safety, Health Care Related Infections (HCRIs) stand out. These infections increase the length of hospital stay, as well the health care costs and even morbidity and mortality ${ }^{(4-5)}$.

One of the strategies for reducing HCRIs and promoting the quality of disease prevention and control actions refers to the creation of Hospital Infection Control Programs (HICPs) ${ }^{(6-9)}$. According to Ordinance No. 2616, of May $12^{\text {th }}, 1998$, the HICPs are a set of actions deliberately and systematically developed, with a view to reducing incidence and severity of infections to the maximum possible ${ }^{(6)}$.

However, the implementation of strategies related to the HICPs still faces serious challenges, especially in developing countries ${ }^{(7)}$. The problems include lack of government incentive, inadequate financial support, discrepancies in relation to the team's roles, behavioral factors and weaknesses in the

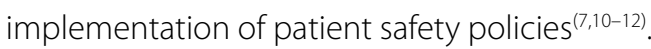

This study may show health care professionals an overview of the quality of the infection control programs, targeting structural components, processes, and outcomes that impact on the prevention and control of the HCRIs. It is expected that this integrative review will provide subsidies that assist in the construction of new national guidelines and recommendations related to the theme.

The objective, therefore, was to analyze the quality of health in relation to the components of structure, process, and outcome in actions for the prevention and control of infections.

\section{METHOD}

This is an integrative literature review study that covered the following methodological stages: (1) establishing the hypothesis or research question; (2) sampling or searching in the literature; (3) categorizing the studies; (4) evaluating the studies included in the review; (5) interpreting the results, and (6) knowledge synthesis ${ }^{(13)}$.

The construction of this article was guided by the Preferred Reporting Items for Systematic Reviews and Meta-Analysis (PRISMA) aiming to increase the quality and reliability of the information obtained. Although PRISMA is a document developed for systematic reviews and meta-analyses, the topics contributed to the construction of all the methodological stages of the study ${ }^{(14)}$.

The PICO strategy was used to elaborate the research question: $\mathrm{P}=$ Population; (I) Intervention (or exposure); (C) Comparison; and (O) Outcome. This procedure sought to strengthen the Evidence-Based Practice (EBP) through a well-structured problem for maximum recovery of articles in the literature ${ }^{(15)}$. The following guiding question was formulated: "What is the outlook for the Hospital Infection Control Programs in relation to the quality components?"

The search for articles included the Latin American and Caribbean Literature in Health Sciences (Literatura Latino-Americana e do Caribe em Ciências da Saúde, LILACS), Web of Science, and Scopus databases, as well as the Scientific Electronic Library Online (SciELO) electronic library. As a strategy for retrieving scientific information, the following MeSH descriptors were crossed: Hospital Infection Control Program, Cross Infection, Quality of Health Care and Infection Control. These descriptors were used in the search with the help of the Boolean operators (AND and OR). For the survey of articles in SciELO, the same words translated into Portuguese were used. It was chosen to disregard the use of quotation marks to expand articles, avoiding possible losses in the initial survey.

The inclusion criteria were complete, open access articles published between January 2009 and May 2019, in Portuguese, English, and Spanish. The exclusion criteria corresponded to reflection articles, editorials, non-systematic literature reviews, books, manuals, and other texts that did not have a peer review process, and/or that did not specifically address the object of study. The studies were exported to the Mendeley software and, later on, those duplicated in two or more databases were excluded (Figure 1). 


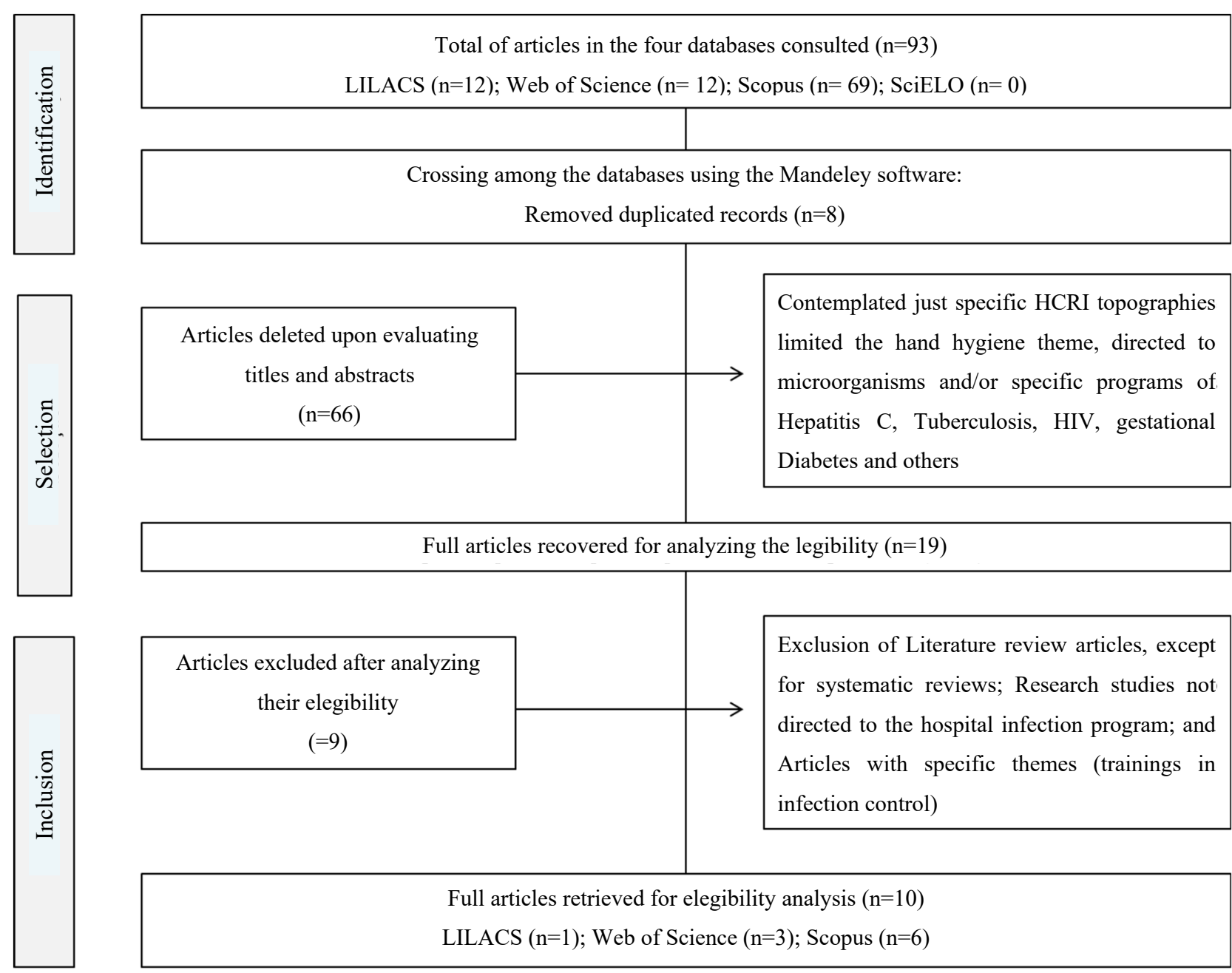

Figure 1 - Draft of the articles included in the integrative literature review Source: Research data, 2019.

The selection of the articles was carried out in June 2019. An eligibility assessment form was adopted, prepared by the Ministry of Health and adapted by the researchers themselves ${ }^{(16)}$. In this case, the criteria to be used were the following: (1) identification of the article (author's last name, name of the journal, year of publication, volume, and number of pages); (2) eligibility criteria, adapted (Was the article peer-reviewed?; Does the article evaluate the quality requirements applied to the Hospital Infection Control Program?; Do the results and conclusions answer the PICO question?) and (3) confirmation for eligibility (Considering the study design, the intervention, and the population involved, can the study be included?).

To assess the methodological quality, the tool for the evaluation of accuracy in observational studies was used ${ }^{(17)}$. Each of the 10 questions receives 1 point when the answer is positive. The final classification can vary from 8 to 10 (high),
5 to 7 (medium), and 0 to 4 (low). In the case of the systematic review articles included in this study, the Assessment of Multiple Systematic Reviews (AMSTAR) was used, which submits 14 items of methodological quality assessment, without establishing cut-off points ${ }^{(18)}$.

The level of evidence from the studies was categorized according to the recommendations of the Agency of Healthcare Research and Quality (AHRQ), with level 1 being a systematic review or meta-analysis of controlled clinical trials; level 2, a well-designed randomized controlled clinical trial; level 3, a controlled clinical trial without randomization; level 4, a well-designed cohort or case-control studies; level 5, a systematic review of qualitative and descriptive studies; level 6, descriptive or qualitative studies, and level 7, expert opinion $^{(19)}$.

Data was transferred to a synoptic table for knowledge synthesis. For analyzing the information, the Microsoft Excel 
2013 program was used, having performed simple descriptive statistics, submitting absolute numbers and percentages. The results of the studies included in the review were coded for similarity and subsequently analyzed by content categorization, making it possible to develop a narrative synthesis.

This study did not involve research with human beings, exempting it from approval by the Research Ethics Committee (REC).

\section{Q RESULTS}

The final sample consisted of 10 articles published in the four databases evaluated, mainly in Scopus (60\%) and in Web of Science (30\%). Only 1 (10\%) study captured in LILACS met the inclusion criteria.

The majority (70\%) of the articles was published in the English language. The origin countries of the publications were the following: Brazil (20\%), Africa (10\%), Germany (10\%), Australia (10\%), Colombia (10\%), United States (10\%), Netherlands (10\%), and Iran (10\%). Only one study (10\%) was conducted simultaneously between the countries of Europe and Asia. Regarding the field of knowledge, all (100\%) of the journals were in the health area, namely: PLoS ONE (20\%), American Journal of Infection Control (10\%), BMJ Open (10\%), Colombia Medical (10\%), Infection, Disease and Health (10\%), International Journal for Quality in Health Care (10\%), Iranian Red Crescent Medical Journal (10\%), Revista da Escola de Enfermagem da USP (10\%), and Revista de Saúde Pública (10\%) (Table 1).

With a balance between the years of publication, the years with the greatest number of publications were 2016 (20\%), 2015 (20\%), and 2014 (20\%). In 2013, no articles were captured in the selected databases. Despite searches in the literature, no explanation was found for the reasons. Regarding the design, it is highlighted that, mostly, the studies were cross-sectional and descriptive (60\%), and had health services as the study scenario (80\%). All (100\%) of the studies showed high methodological quality, but with low levels of evidence (Chart 1).

As for the topics covered, most of the articles included at least one quality component related to the $\mathrm{HICP}$, with three categories of analysis emerging: (1) structural elements of hospital infection control programs (2) considerations on process evaluation in infection control and (3) the influence of the outcome component as a strategy for improving the HICP.

\section{Structural elements of hospital infection control programs}

Most of the studies (70\%) addressed the structural as-

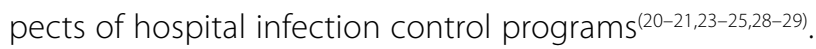
The physical facilities, the organizational characteristics, and the human and material resources were highlighted among the publications.

Two articles showed several weaknesses attributed to the HICP of the African countries, highlighting the inadequate infrastructure for the prevention and control of $\mathrm{HCRIs}^{(24,28)}$. The authors described that only $13 \%$ of the services had an active HICC, 11\% still recycled procedure gloves and that just over half (52\%) had running water and appropriate supplies for hand hygiene ${ }^{(28)}$.

A number of studies carried out in Brazil showed good performance in the evaluation of the parameters of the technical-operational structure, finding compliance rates that varied from 80 to 100\%(20,29). However, there was certain lack of data on the quality of the HICP from institutions in the Unified Health System (Sistema Único de Saúde, SUS) network. These successful results diverged from a survey conducted in the countries of Europe and Asia, which indicated opportunities for improvement in relation to the use of Personal Protective Equipment (PPE) and of the isolation areas ${ }^{(21)}$.

Regarding human resources, 30\% of the articles explained the need to expand the number of infection controllers to meet the organizational demands ${ }^{(21,23,25)}$. Two studies recommended the adequacy of the number of these professionals according to the proportion of the number of beds ${ }^{(23,25)}$.

\section{Considerations on the evaluation of the infection control process}

Most of the studies (60\%) highlighted some operational actions for the prevention and control of infection ${ }^{(20,25-29)}$. Brazilian researchers observed that the process of the implanted routines was not uniform among the evaluated hospitals ${ }^{(20)}$. Other data emphasized the small number of professionals with specific qualifications, generating inconsistencies in compliance with published guidelines ${ }^{(27)}$.

In Colombia, $65 \%$ of the HCRI surveillance activities are carried out in a combined manner, using the active and passive surveillance format. In addition, it was perceived 
Table 1 - Characterization of the studies included in the integrative literature review. Brazil, 2009-2019 (n=10).

Variables

Language

English

Portuguese

Spanish

Country of study

Africa

Germany

Australia

Brazil

Colombia

United States

Eurasia*

Netherlands

Iran

Journals

American Journal of Infection Control

BMJ Open

Colombia Médica

Infection, Disease and Health

International Journal for Quality in Health Care

Iranian Red Crescent Medical Journal

PLOS ONE

Revista da Escola de Enfermagem da USP

Public Health Magazine

Knowledge Area

Health n

1

\section{$\%$}

70.0

20.0

10.0

10.0

10.0

10.0

20.0

10.0

10.0

10.0

10.0

10.0

10.0

10.0

10.0

10.0

10.0

10.0

20.0

10.0

10.0

1

100.0

Source: Research data, 2009-2019.

*Eurasia = European and Asian countries (Turkey, Pakistan, Russia, Georgia, Kosovo, Bulgaria, Oman, Iran, India, and Kazakhstan). 


\begin{tabular}{|c|c|c|c|}
\hline $\begin{array}{l}\text { Author } \\
\text { and year }\end{array}$ & $\begin{array}{l}\text { Design and } \\
\text { scenario }\end{array}$ & $\begin{array}{l}\text { Methodological } \\
\text { quality and level } \\
\text { of evidence }\end{array}$ & Main highlights \\
\hline $\begin{array}{l}\text { Giroti et } \\
\text { al., 2018 }\end{array}$ & $\begin{array}{l}\text { Cross-sectional } \\
\text { and descriptive } \\
\qquad \begin{array}{l}\mathrm{n}=14 \\
\text { (Health } \\
\text { Care Services) }\end{array}\end{array}$ & $\begin{array}{c}\text { Score 9/10 (high); } \\
\text { Level } 6\end{array}$ & $\begin{array}{l}\text { The indicators referring to the technical-operational } \\
\text { structure and the epidemiological surveillance system } \\
\text { for infection had better compliance: } 80.58 \% \text { and } \\
81.59 \% \text {, respectively. However, the indicators on the } \\
\text { operational guidelines and the prevention and control } \\
\text { of infection were not satisfactory, showing that there is } \\
\text { no uniformity in the routines implemented in hospitals. }\end{array}$ \\
\hline $\begin{array}{l}\text { Fletcher et } \\
\text { al., 2017 }\end{array}$ & $\begin{array}{l}\text { Cross-sectional, } \\
\text { descriptive } \\
\quad n=23 \\
\text { (Health Services) }\end{array}$ & $\begin{array}{c}\text { Score 9/10 (high); } \\
\text { Level } 6\end{array}$ & $\begin{array}{l}\text { The authors highlighted opportunities for improvement } \\
\text { in relation to the structure, emphasizing the use of PPE, } \\
\text { isolation for confirmed cases, and an adequate number } \\
\text { of professionals. In addition, they recommended } \\
\text { additional audits to guarantee the quality of the } \\
\text { national programs. }\end{array}$ \\
\hline $\begin{array}{l}\text { Arefian et } \\
\text { al., 2016 }\end{array}$ & $\begin{array}{c}\text { Systematic review } \\
n=27 \\
\text { (Studies) }\end{array}$ & $\begin{array}{l}\text { Score 14/14; } \\
\text { Level } 5\end{array}$ & $\begin{array}{l}\text { Since 2009, the number of publications on HCRI } \\
\text { prevention programs has increased; however, there has } \\
\text { been no improvement in the quality of these studies. } \\
\text { The authors reinforce the importance of making } \\
\text { investments in the HICPs to reduce unnecessary } \\
\text { expenses resulting from infectious events. }\end{array}$ \\
\hline $\begin{array}{l}\text { Mitchell et } \\
\text { al., 2016(23) }\end{array}$ & $\begin{array}{l}\text { Cross-sectional, } \\
\text { descriptive } \\
\begin{array}{l}n=40 \\
\text { (HICCs) }\end{array}\end{array}$ & $\begin{array}{c}\text { Score 9/10 (high); } \\
\text { Level } 6\end{array}$ & $\begin{array}{l}\text { In Australia, approximately } 1,675 \text { hours are spent on } \\
\text { the HCRI surveillance process, which increases as the } \\
\text { number of beds goes up. For the authors, the success } \\
\text { of the surveillance program depends on the ability } \\
\text { to provide information to those who can implement } \\
\text { changes and act as an incentive for continuous } \\
\text { team participation. }\end{array}$ \\
\hline $\begin{array}{l}\text { Van } \\
\text { Mourik et } \\
\text { al., 2015(24) }\end{array}$ & $\begin{array}{c}\text { Systematic review } \\
\qquad \mathrm{n}=35 \\
\text { (Studies) }\end{array}$ & $\begin{array}{l}\text { Score 10/14; } \\
\text { Level } 5\end{array}$ & $\begin{array}{l}\text { In Africa, little has been invested in the HICP. Improper } \\
\text { infrastructure, inadequate infection prevention } \\
\text { practices, as well as lack of laboratory input negatively } \\
\text { influence the indicators, generating underreporting. }\end{array}$ \\
\hline $\begin{array}{l}\text { Hernández- } \\
\text { Gómez et } \\
\text { al., 2015(25) }\end{array}$ & $\begin{array}{c}\text { Descriptive } \\
n=23 \\
\text { (Health Services) }\end{array}$ & $\begin{array}{c}\text { Score 9/10 (high); } \\
\text { Level } 6\end{array}$ & $\begin{array}{l}\text { Regarding the structure, it is necessary to increase the } \\
\text { proportion of professionals per number of beds. In the } \\
\text { process evaluation, it is highlighted that } 65 \% \text { perform } \\
\text { the surveillance of HCRIs in a combined way (active } \\
\text { and passive), using the NHSN criterion of the CDC, from } \\
\text { the United States. The HCRI results are compiled into } \\
\text { a specific software; however, it could achieve greater } \\
\text { adherence to an active, standardized and prospective } \\
\text { surveillance model. }\end{array}$ \\
\hline
\end{tabular}

Chart 1 - Synoptic chart with the description of the variables of the articles included in the integrative review. Brazil, 2009-2019 $(n=10)$ 


\begin{tabular}{|c|c|c|c|}
\hline $\begin{array}{l}\text { Author } \\
\text { and year }\end{array}$ & $\begin{array}{l}\text { Design and } \\
\text { scenario }\end{array}$ & $\begin{array}{l}\text { Methodological } \\
\text { quality and level } \\
\text { of evidence }\end{array}$ & Main highlights \\
\hline $\begin{array}{l}\text { Shojaee et } \\
\text { al., 2014(26) }\end{array}$ & $\begin{array}{c}\text { Cross-sectional, } \\
\text { descriptive } \\
n=23 \\
\text { (Health Services) }\end{array}$ & $\begin{array}{c}\text { Score 9/10 (high); } \\
\text { Level } 6\end{array}$ & $\begin{array}{l}\text { Six sessions related to the HICP were evaluated: } \\
\text { leadership and programming; program focus; isolation } \\
\text { methods; health and hand protection techniques; } \\
\text { improvement in safety and quality of patients and } \\
\text { staff training, where most items presented adequate } \\
\text { conditions, with compliance records above } 77 \% \text {, except } \\
\text { for isolation methods (67.4\%). }\end{array}$ \\
\hline $\begin{array}{l}\text { Stone et } \\
\text { al., 2014(27) }\end{array}$ & $\begin{array}{l}\text { Cross-sectional, } \\
\text { descriptive } \\
n=3,374 \\
\text { (Health Services) }\end{array}$ & $\begin{array}{c}\text { Score 10/10 (high); } \\
\text { Level } 6\end{array}$ & $\begin{array}{l}\text { The authors showed that there are few professionals } \\
\text { working at the HICC with specific degrees and these } \\
\text { are not consistent with the published guidelines. It is } \\
\text { added that little time is invested in health education to } \\
\text { prevent infection. }\end{array}$ \\
\hline $\begin{array}{l}\text { Friday et } \\
\text { al., 2012 }\end{array}$ & $\begin{array}{l}\text { Cross-sectional } \\
\text { Descriptive } \\
n n=63 \\
\text { (Health Services) }\end{array}$ & $\begin{array}{c}\text { Score } 8 / 10 \text { (high); } \\
\text { Level } 6\end{array}$ & $\begin{array}{l}\text { About the structure, only } 13 \% \text { of the services had HICC, } \\
52 \% \text { of the locations had running water in } 24 \text { hours, few } \\
\text { supplies were available for hand hygiene, and } 11 \% \text { still } \\
\text { recycled gloves. Regarding the process component, } \\
63 \% \text { reported having infection control procedures and } \\
33 \% \text { said they had a training program. }\end{array}$ \\
\hline $\begin{array}{l}\text { Silva et } \\
\text { al., } 2011^{(29)}\end{array}$ & $\begin{array}{c}\text { Methodological and } \\
\text { descriptive study } \\
n=50 \\
\text { (Health Services) }\end{array}$ & $\begin{array}{c}\text { Score } 8 / 10 \text { (high); } \\
\text { Level } 6\end{array}$ & $\begin{array}{l}\text { The "structure" and "epidemiology" indicators showed } \\
\text { 100\% compliance for almost all the assessments. The } \\
\text { greatest conformities, with statistical significance, } \\
\text { were in the group of institutions with qualification or } \\
\text { accreditation processes in health. }\end{array}$ \\
\hline
\end{tabular}

Chart 1 - Cont.

Source: Research data, 2019

Note: $\mathrm{HICC}=$ Hospital Infection Control Commission; CDC = Centers for Disease Control and Prevention; NHSN = National Healthcare Safety Network.

that most of the 23 health services evaluated follow the NHSN methodology of the CDC, from the United States ${ }^{(25)}$.

Three articles included in this integrative review suggested improvements in relation to the health education process carried out by the HICC ${ }^{(26-28)}$. In the United States, the researchers concluded that little time is invested in qualifications and training ${ }^{(27)}$. Corroborating this, it is highlighted that only $33 \%$ of the health services in Nigeria have an active training program and not more than $11 \%$ investigate maternal deaths related to infection ${ }^{(28)}$.

\section{The influence of the outcome component as a strategy to improve the HICP}

In their systematic review, the authors reinforced the importance of investments in the HICP to improve the quality of infectious indicator( ${ }^{(22)}$. A multicenter study showed that the success of the program depends on the ability to provide information to the managers that can promote changes and act as an incentive for continued participation in infection control actions ${ }^{(23)}$. However, the outcome component was not emphasized among the other articles in this review.

Two studies showed compliance rates above $77 \%$ related to the HICP results, attributing the best outcomes to institutions with qualification or accreditation processes in health ${ }^{(26,29)}$. A suggested improvement recommended for the success of the HICP refers to conducting additional audits to ensure the quality of the infection indicators ${ }^{(21)}$.

\section{DISCUSSION}

The scope of the HICP must establish a minimum structure necessary for the prevention and control of the HCRIs. The studies that evaluated the infrastructure characteristics 
showed that there is no minimum quality standard recommended among the health services ${ }^{(20-21,23-25,28)}$. This occurred mainly in developing countries that presented the greatest precariousness of this evaluation component ${ }^{(24)}$.

In the African countries, the researchers raised several weaknesses attributed to the HICP, highlighting the low investment in systemic actions that reduce the incidence and magnitude of infectious diseases ${ }^{(24,28)}$. It is known that the best care practices are ensured through compliance with the current guidelines, emphasizing hand hygiene, the use of PPE, and the adequate training of human resources ${ }^{(30)}$.

The structural elements impact on the success of prevention and infection control actions, where it was possible to survey in the literature that national hospitals need to adapt the physical space due to the fact that they share the same location with other administrative sectors ${ }^{(20)}$. This data contradicts the recommendations described in the current legislation on the obligation to provide all the necessary resources for the performance of the HICC (6).

With regard to human resources, the researchers from Australia measured the time spent on the surveillance of HCRIs and pointed out that 1,675 hours are spent on this activity in the total of 4,653 hours ${ }^{(23)}$. Corroborating this, the authors indicated that the appropriate proportion of infection controllers should be established according to the size of the hospital (25). Epidemiological surveillance activities, outbreak investigations, training, and qualifications only happen properly when there are enough professionals to carry out the planned actions ${ }^{(31)}$.

In Brazil, the HICC's operational guidelines and specific activities still need to be improved among the services ${ }^{(20)}$. It is noteworthy that the success of infection prevention and control actions includes the involvement of all the professionals, patients, and family members ${ }^{(11)}$. Quality assurance in health requires commitment, dedication, implementation of good practices, and constant updates by the multidisciplinary team. One of the challenges is to ensure that process measurement is widely encouraged, even in health services with low financial investment.

In this sense, the focus of Brazilian studies on structural and process evaluations is highlighted, mainly in the survey of indicators of permanent education as a quality requirement for preventing $\mathrm{HCRI}^{(7-9)}$. Moreover, the organizational context does not contribute to the success of the program, and there are still difficulties in implementing the recommendations and weaknesses in the implementation of patient safety policies ${ }^{(10-12)}$

In the United States, although the network of hospitals performs satisfactorily in relation to the HICP, the time invested in training that prevents, for example, urinary tract infection, is still limited ${ }^{(27)}$. A study carried out in Nigeria showed a deficit in a training program for infection control in maternity hospitals ${ }^{(28)}$. In this context, infection controllers are committed to reducing HCRIs by using health education actions with the professionals. There are several strategies that can be used in the practice to stimulate the team, highlighting parodies, posters, phrases permeated with a touch of humor and even information technology software, which makes the working hours of the professionals involved more flexible ${ }^{(32)}$.

The result of the actions developed by the HICC with a view to reducing the incidence of the HCRIs impacts on the quality indicators, considered an important component that reflects the care provided by the team ${ }^{(33)}$. The indicators envisage the excellence of care and provide better organizational outcomes; however, from the point of view of the studies included in this review, this component did not stand out much.

Through infectious indicators, it is possible to measure the quality of the interdisciplinary care provided to the patient and to detect possible failures related to work processes ${ }^{(33)}$. A systematic review stated that investments made in the HICP provide improvements in institutional results ${ }^{(22)}$. Furthermore, the incentive of the health managers to carry out the actions planned by the HICC was considered a factor that contributes to the promotion of the set of actions developed by the program ${ }^{(23)}$

A number of studies have recommended additional audits and health accreditation processes aimed at improving indicators through systematic actions developed by the HICC ${ }^{(21,29)}$. Among the various benefits of hospital accreditation, the changes in the behavior of the professionals and in patient satisfaction stand out. In this sense, the organizational advances resulting from this process contribute to better decision making, thus guaranteeing patient safety ${ }^{(34-35)}$.

This study represented an advance for teaching and research because the elaboration stages were developed with methodological rigor, using instruments validated in the literature that allowed for a more critical assessment of the studies included in this review. In addition, understanding the quality components of the hospital infection control programs will contribute to the planning of systematic actions that seek innovation in the practice of health professionals, providing safe and harm-free care.

As limitations of the study, it is highlighted that the time delimitation may have contributed to the non-inclusion of articles that answer the research question, which may be published before the defined period. Moreover, there were no interpretations by the researchers during the categorization 
of articles, explaining only the results of the studies captured in the strategy for retrieving scientific information.

\section{a CONCLUSION}

In this study, it was possible to analyze the hospital infection control programs in relation to the quality components, highlighting the need to improve the structure, process, and outcome. It was observed that the organizational characteristics are diversified among the countries, that the activities developed do not comply with the evidence-based guidelines, and that there is still a need to emphasize infection indicators that reflect the excellence of patient care.

In general, it is highlighted that the actions developed by the HICP have great variation in the literature, presenting suggestions for improvements to be worked on by the health managers to reduce the magnitude of the HCRIs. It is hoped that this study has provided subsidies that contribute to the construction of new guidelines and recommendations linked to the theme.

\section{REFERENCES}

1. Agência Nacional de Vigilância Sanitária (BR). Assistência segura: uma reflexão teórica aplicada à prática. Brasília, DF: Anvisa; 2017 [citado 2019 set 10]. Disponível em: http://portal.anvisa.gov.br/documents/33852/3507912/ Caderno+1+-+Assist\%C3\%AAncia+Segura++Uma+Reflex\%C3\%A

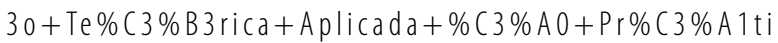
ca/97881798-cea0-4974-9d9b-077528ea1573

2. Gilmartin HM, Sousa KH. Testing the Quality Health Outcomes Model applied to infection prevention in hospitals. Qual Manag Health Care. 2016;25(3):149-61. doi: https://doi.org/10.1097/0MH.0000000000000102

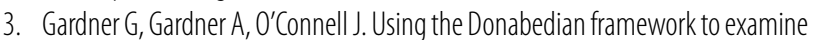
the quality and safety of nursing service innovation. J Clin Nurs. 2014;23(12):145-55. doi: https://doi.org/10.1097/10.1111/jocn.12146

4. Manoukian S, Stewart S, Dancer S, Graves N, Mason H, McFarland A et al. Estimating excess length of stay due to healthcare-associated infections: a systematic review and meta-analysis of statistical methodology. J Hosp Infect. 2018;100(2):222-35. doi: https://doi.org/10.1016/j.jhin.2018.06.003

5. Storr J, Twyman A, Zingg W, Damani N, Kilpatrick C, Reilly J, et al. Core components for effective infection prevention and control programmes: new WHO evidence-based recommendations. Antimicrob Resist Infect Control. 2017;6:6. doi: https://doi.org/10.1186/s13756-016-0149-9

6. Ministério da Saúde (BR). Portaria № 2616, de 12 de maio de 1998. Expede na forma dos anexos I, II, III, IV e V, diretrizes e normas para prevenção e 0 controle das infecções hospitalares. Brasília, DF; 1998 [citado 2019 set 10]. Disponível em: https://bvsms.saude.gov.br/bvs/saudelegis/gm/1998/prt2616 _12_05_1998.html

7. Padoveze MC, Fortaleza CM, Kiffer C, Barth AL, Carneiro IC, Giamberardino HI, et al. Structure for prevention of health care-associated infections in Brazilian hospitals: a countrywide study. Am J Infect Control. 2016;44(1):74-9. doi: https://doi.org/10.1016/j.ajic.2015.08.004
8. Menegueti MG, Canini SRMS, Bellissimo-Rodrigues F, Laus AM. Evaluation of nosocomial infection control programs in health services. Rev Latino-Am Enfermagem.2015;23(1):98-105.doi:https://doi.org/10.1590/0104-1169.011 3.2530

9. Alves DCI, Lacerda RA. Evaluation of programs of infection control related to healthcare assistance in hospitals. Rev Esc Enferm USP. 2015;49(spe):65-73. doi: https://doi.org/10.1590/S0080-623420150000700010

10. Cavalcante EFO, Pereira IRBO, Leite MJVF, Santos AMD, Cavalcante CAA. Implementação dos núcleos de segurança do paciente eas infecções relacionadas à assistência à saúde. Rev Gaúcha Enferm. 2019; 40(spe):e20180306. doi: https://doi.org/10.1590/1983-1447.2019.20180306

11. Oliveira HM, Silva CPR, Lacerda RA. Policies for control and prevention of infections related to healthcare assistance in Brazil: a conceptual analysis. Rev Esc Enferm USP. 2016;50(3):505-11. doi: https://doi.org/10.1590/S00 80-623420160000400018

12. Zingg W, Holmes A, Dettenkofer M, Goetting T, Secci F, Clack L, et al. Hospital organisation, management, and structure for prevention of health-careassociated infection: a systematic review and expert consensus. Lancet Infect Dis. 2015;15(2):212-24. doi: https://doi.org/10.1016/S1473-3099(14)70854-0

13. Soares CB, Hoga LAK, Peduzzi M, Sangaleti C, Yonekura T, Silva DRAD. Integrative review: concepts and methods used in nursing. Rev Esc Enferm USP. 2014;48(2):335-45. doi: https://doi.org/10.1590/S0080-623420140000 2000020

14. Fuchs SC, Paim BS. Meta-analysis and systematic review of observational studies. Rev HCPA. 2010 [cited Aug 20, 2019];30(3):294-301. Available from: https://lume.ufrgs.br/bitstream/handle/10183/157837/000835622.pdf? sequence $=1 \&$ isAllowed $=y$

15. Eriksen MB, Frandsen TF. The impact of patient, intervention, comparison, outcome (PICO) as a search strategy tool on literature search quality: a systematic review. J Med Livr Assoc. 2018;106(4):420-31. doi: https://doi. org/10.5195/jmla.2018.345

16. Ministério da Saúde (BR). Secretaria de Ciência, Tecnologia e Insumos Estratégicos Departamento de Ciência e Tecnologia. Diretrizes metodológicas: elaboração de revisão sistemática e metanálise de ensaios clínicos randomizados. Brasília, DF: Ministério da Saúde; 2012 [citado 2019 set 10]. Disponível em: https:// bvsms.saude.gov.br/bvs/publicacoes/diretrizes_metodologicas_elaboracao_ sistematica.pdf

17. Munn Z, Moola S, Riitano D, Lisy K. The development of a critical appraisal tool for use in systematic reviews addressing questions of prevalence. Int J Health Policy Manag. 2014;3(3):123-8. doi: https://doi.org/10.15171/ijhpm.2014.71

18. Costa AB, Zoltowski APC, Koller SH, Teixeira MAPA. Construção de uma escala para avaliar a qualidade metodológica de revisões sistemáticas. Ciênc Saúde Coletiva. 2015;20(8):2441-52. doi: https://doi.org/10.1590/ 1413-81232015208.10762014

19. Galvão CM. Evidence hierarchies [Editorial]. Acta Paul Enferm. 2006;19(2):5-5. doi: https://doi.org/10.1590/S0103-21002006000200001

20. Giroti ALB, Ferreira AM, Rigotti MA, Sousa ÁFL, Frota OP, Andrade D. Hospital infection control programs: assessment of process and structure indicators. Rev Esc Enferm USP. 2018;52:e03364. doi: https://doi.org/10.1590/s1980220x2017039903364

21. Fletcher TE, Gulzhan A, Ahmeti S, Al-Abri SS, Asik Z, Atilla A, et al. Infection prevention and control practice for Crimean-Congo hemorrhagic fever: a multicenter cross-sectional survey in Eurasia. PLoS One. 2017;12(9):e0182315. doi: https://doi.org/10.1371/journal.pone.0182315 
22. Arefian H, Vogel M, KwetkatA, Hartmann M. Economic evaluation of interventions for prevention of hospital acquired infections: a systematic review. PLOS One. 2016;11(1):e0146381. doi: https://doi.org/10.1371/journal.pone.0146381

23. Mitchell BG, Hall L, Halton K, MacBeth B, Gardner A. Time spent by infection control professionals undertaking healthcare associated infection surveillance: a multi-centred cross sectional study. Infect Dis Health. 2016;21(1):36-40. doi: https://doi.org/10.1016/j.idh.2016.03.003

24. Van Mourik MSM, Van Duijn PJ, Moons KGM, Bonten MJM, Lee GM. Accuracy of administrative data for surveillance of healthcare-associated infections: a systematic review. BMJ Open. 2015;5:e008424. doi: https://doi.org/10.1136/ bmjopen-2015-008424

25. Hernández-Gómez C, Motoa G, Vallejo M, Blanco VM, Correa A, de la Cadena E, et al. Introduction of software tools for epidemiological surveillance in infection control in Colombia. Colomb Med (Cali). 2015 [cited Aug 20 2019];46(2):60-5. Available from: https://www.ncbi.nlm.nih.gov/pmc/articles/PMC4536816/ pdf/1657-9534-cm-46-02-00060.pdf

26. Shojaee J, Moosazadeh M. Determining the status quo of infection prevention and control standards in the hospitals of Iran: a case study in 23 Hospitals. Iran Red Crescent Med J. 2014;16(2):e14965. doi: https://doi.org/10.5812/ircmj.14695

27. Stone PW, Pogorzelska-Maziarz M, Herzig CT, Weiner LM, Furuya EY, Dick A, et al. State of infection prevention in US hospitals enrolled in the National Health and Safety Network. Am J Infect Control. 2014;42(2):94-9. doi: https://doi. org/10.1016/j.ajic.2013.10.003

28. Friday 0, Edoja 0, Osasu A, Chinenye N, Cyril M, Lovney K, et al. Assessment of infection control practices in maternity units in Southern Nigeria. Int J Qual Health Care. 2012;24(6):634-40. doi: https://doi.org/10.1093/intqhc/mzs057
29. Silva CPR, Lacerda RA. Validation of a proposal for evaluating hospital infection control programs. Rev Saúde Pública. 2011;45(1):121-8. doi: https://doi. org/10.1590/S0034-89102010005000052

30. Haque M, Sartelli M, McKimm J, Abu Bakar M. Health care-associated infections: an overview. Infect Drug Resist. 2018;2018:2321-33. doi: https:// doi.org/10.2147/IDR.S177247

31. Bryant KA, Harris AD, Gould CV, Humphreys E, Lundstrom T, Murphy DM, et al. Necessary infrastructure of infection prevention and healthcare epidemiology programs: a review. Infect Control Hosp Epidemiol. 2016;37(4):371-80. doi: https://doi.org/10.1017/ice.2015.333

32. Massaroli A, Martini JG, Massaroli R. Educação permanente para 0 aperfeiçoamento do controle de infecção hospitalar: revisão integrativa. Saúde Transform Soc. 2014 [citado 2019 ago 21];5(1):7-15. Available from: http:// pepsic.bvsalud.org/pdf/sts/v5n1/5n1a03.pdf

33. Báo ACP, Amestoy SC, Moura GMSS, Trindade LL. Quality indicators: tools for the management of best practices in health. Rev Bras Enferm. 2019;72(2):377-84. doi: https://doi.org/10.1590/0034-7167-2018-0479

34. Siegfried A, Heffernan M, Kennedy M, Meit M. Quality improvement and performance management benefits of public health accreditation: national evaluation findings. J Public Health Manag Pract. 2018;24(3):S3-S9. doi: https://doi.org/10.1097/PHH.0000000000000692

35. Mendes GHS, Mirandola TBS. Acreditação hospitalar como estratégia de melhoria: impactos em seis hospitais acreditados. Gest Prod. 2015;22(3):63648. doi: https://doi.org/10.1590/0104-530X1226-14

\section{- Corresponding author:}

André Luiz Silva Alvim

E-mail: andrealvim1@hotmail.com

\section{Associate editor:}

Dagmar Elaine Kaiser 